\title{
高齢者における洪水災害後のPTSD 症状発現の特徵
}

\author{
災害前の健康状態と地域交流の程度に注目して \\ ○高岸幸弘 ${ }^{1} \cdot$ 安部幸志 ${ }^{2} \cdot$ 板山昂 ${ }^{3}$ \\ ( ${ }^{1}$ 熊本大学教育学部・ ${ }^{2}$ 鹿児島大学法文学部・ ${ }^{3}$ 関西国際大学人間科学部) \\ キーワード：自然災害・PTSD・高齢者
}

Characteristics on development of PTSD symptoms after suffering from flooding disaster among elderly people Yukihiro TAKAGISHI ${ }^{1}$, Koji $\mathrm{ABE}^{2}$ and Akira ITAYAMA ${ }^{3}$

( ${ }^{1}$ Faculty of Education, Kumamoto Univ., ${ }^{2}$ Faculty of law, economics and humanities, Kagoshima Univ., and ${ }^{3}$ School of Human Sciences,

Kansai University of International Studies)

Key Words: natural disaster, PTSD, and elderly

\section{目 的}

大きな災害の被災によるその後の PTSD 症状の発症は、そ の災害規模が大きければ大きいほど深刻であることが報告さ れている(Maes et al., 2001)。しかしながら、近年では被災規 模に関わらず（人的被害含む）、特に高齢者の集落などは復 興に困難が生じたり、心理的な被害が大きかったりすること が報告されており、災害の規模のみによる事態の理解は適切 な援助につながらないといえる (Abe et al., 2016)。

本研究では、2014 年に兵庫県丹波市で起きた大雨と洪水 によって被害を受けた地域の住民を対象に、アンケート調査 を行った。対象とした地域は、住民のほとんどが高齢者であ り、洪水被害そのものはそれほど大きく報道されなかった が、物理的な復興がスムーズに行われていない地域である。

これまでの調査研究では、死者数やけが人の数は甚大と言 われるほどではなかったものの（それぞれ 1 名と 4 名）、3 割以上の住民が中程度から深刻なうつ症状を呈していたこと が報告されている（Abe et al., 2016）。特に住民とのつながり を表すソーシャルキャピタルがそしい場合にはうつ症状が上 昇していた。本研究では、PTSD 症状（侵入・回避・過覚 醒）に注目し、ソーシャルキャピタルを含む、その他どのよ うな要因が PTSD 症状の発現に影響しているかを調べた。

\section{方 法}

大雨による洪水被害を受けた兵庫県丹波市の A 地区で全 住民 289 名 (男性 136 名, 女性 153 名)を対象に、災害発生の 12 ケ月後にアンケート調査を実施した。

アンケートでは、性別・年齢といった人口統計学の值と、 PTSD 症状を測定する IES-R、抑うつ症状 15 項目 2 件法、主 観的不健康度・日頃の悩み（の量）についてそれぞれ 1 項目 5 件法と 4 件法で、近所づきあいや地域行事への参加などソ ーシャルキャピタルの有無を 4 項目 2 件法で回答を求めた。

\section{結 果}

アンケート調査の結果、IES-R の得点が PTSD 発症の判断 の 1 つの基準となるカットオフポイントの 25 点以上だった 回答者は全体の $34.0 \%(\mathrm{n}=109)$ であった。

(1) 相関分析

IES-R 得点は高齢、不健康度、日頃の悩みと正の相関がみ られ、ソーシャルキャピタルとは負の相関がみられた。ソー シャルキャピタルは全ての変数と負の相関がみられた。高齢 は不健康度と正の相関があった一方で、日頃の悩みとには有 意な相関がなかった。

(2) 共分散構造分析 (SEM)

共分散構造分析に先立ち、各変数の性差を $\mathrm{t}$ 検定で確認し たところ、有意な差はみられなかった。
その後アウトカムとして抑うつ症状とトラウマ症状を設定 し、理論的見地から、独立変数としての年齢、日頃の悩み、 主観的不健康、ソーシャルキャピタルを下図のように配置し たSEMを行った。有意でないパスを削除し解析を繰り返し た結果、抑うつ症状には年齢を除くすべての変数からのパス が有意となっていたが、トラウマ症状には日頃の悩みと主観 的不健康度からのパスおよび年齢からの直接のパスが有意で あり、ソーシャルキャピタルは有意ではなかった。

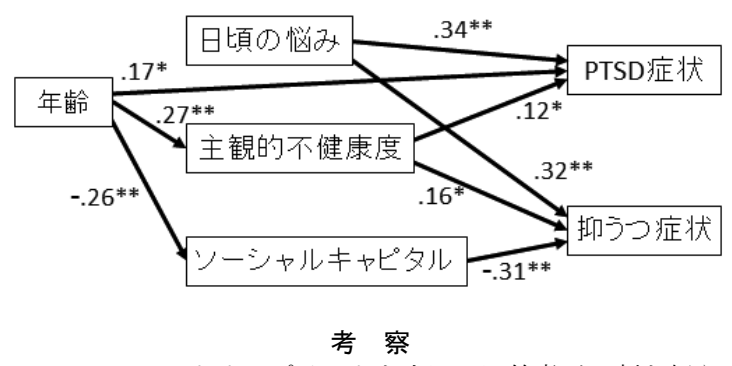

IES-R のカットオフポイントを上回る回答者が 3 割を超え ていたことは、災害の被災規模が表面的には甚大ではない災 害であったとしても、被災者の心理的ダメージは大きい可能 性があることを示しており、介入時には考慮す心゙きことだと 言える。

先行研究では、抑うつ症状をアウトカムとした場合、ソー シャルキャピタルはその発現に影響を及ぼす重要な因子であ ったが、PTSD 症状ではソーシャルキャピタルよりも、もと もとの健康状態や日頃の悩みの多さがその発現に影響してい た。単純な相関では、ソーシャルキャピタルは PTSD 症状と 負の関係にあったが、SEM では、年齢や健康状態といった 身体的要因や日頃の悩みという心理的要因が影響因であっ た。これはうつ症状がより社会的要因の影響を受けやすいと いうこと、そして PTSD 症状がより生物学的要因の影響を受 けて発現しや寸いということを示しているともいえよう。

災害後の PTSD 発症を予防寸るためには、日頃からの健康 の維持や心理的ケアが重要であるといえる。

\section{引用文献}

Abe, K, Takagishi, Y., \& Itayama, A. (2016). Depression symptoms among senior survivors of post flood-disaster area in Japan. $31^{\text {st }}$ International Congress of Psychology, PS27P-07-80, 238.

Maes, M., Mylle, J., Delmeire, L., \& Janca, A. (2001). Pre-and post-disaster negative life events in relation to the incidence and severity of post-traumatic stress disorder. Psychiatry research, $105,1-12$. 